Check for updates

Belfast

chrisbaraniuk@gmail.com

Cite this as: BMJ2020;369:m2284 http://dx.doi.org/10.1136/bmj.m2284 Published: 24 June 2020

Q\&A

\title{
Covid-19 antibody tests: a briefing
}

\section{Antibody tests are a potentially useful tool in the pandemic response-but what are they, how do they work, and are they all the same? Chris Baraniuk explains}

\section{Chris Baraniuk freelance journalist}

\section{What are antibody tests?}

Studies have shown that patients who have survived covid-19 have antibodies associated with the disease in their blood. ${ }^{1}$ Tests can thus be designed to detect those antibodies and indicate whether someone has had covid-19 in the past. However, such tests aren't always accurate, and antibodies can gradually disappear from someone's blood over time.

Antibody tests are different from the standard polymerase chain reaction (PCR) tests for covid-19, which detect the presence of viral RNA in, for example, fluid from a patient's nose or throat. PCR tests can reveal whether someone currently has the virus, but the whole process, including collecting and running samples, means that it can take a day or two to deliver a result (which also makes it expensive-each sample costing around $€ 40-£ 120$ (€45-€130; \$50-\$150)). In principle, antibody tests are a lot faster and cheaper: some can give results in less than 30 minutes with prices around $£ 8$ a sample, although these may not be the most accurate type.

\section{How do the tests work?}

An ideal antibody test is like Cinderella's glass slipper-only one foot will fit. When testing for covid-19, small antigen proteins from the SARS-CoV-2 virus are coated onto a plate. These are then exposed to a blood sample from a patient, and an enzyme and chemical reagent are applied.

If the specific antibodies that target the SARS-CoV-2 virus are present in the blood sample, they will attach to the viral antigens on the plate. The enzyme then sticks to the antibody, which subsequently activates the chemical reagent, causing a colour change or giving off a luminescence that indicates a positive result (in some lab based tests, measuring the amount of light can quantify how many antibodies are present).

These tests can be performed in laboratories, but simpler versions can also be packaged in self-testing kits for people to use at home, using a finger prick to take a blood sample. One big difference is that lab based tests can quantify the number of antibodies in a sample, but self-testing kits merely provide a positive or negative result.

\section{How accurate are the lab tests?}

There are two key measures of an antibody test's quality: its sensitivity and specificity. Highly sensitive tests can accurately detect whether people have antibodies present in their blood. If a test is described as highly specific, this means that it's specific to a particular type of antibody and can also reliably detect people who do not have covid-19 antibodies. The presence of some types of antibodies can give an indication of when a person may have been infected.

So far, the quality of antibody tests for covid-19 vary in quality, but several offer sensitivity and specificity near to or even at $100 \%$, say their manufacturers. ${ }^{2}$ Very occasionally, an antibody test may give a false positive result (suggesting that people have covid-19 antibodies when in fact they do not) because of cross reactivity with coronaviruses other than SARS-CoV-2, for example.

No test can always be $100 \%$ accurate. Lab test kits made by the drug companies Roche and Abbott were evaluated by Public Health England in a series of experiments using samples from confirmed covid-19 patients. Public Health England found that the Abbott test was $93.4 \%$ sensitive and $100 \%$ specific for samples collected two weeks after the patient first showed symptoms. ${ }^{3}$ The Roche tests were $87 \%$ sensitive and $100 \%$ specific. ${ }^{4}$ The lower the sensitivity, the higher the likelihood of false negative results.

\section{What about self-testing?}

Self-test kits are more of a wild west. In April, the UK government purchased two million finger prick self-test kits from two Chinese companies at a cost of $£ 16 \mathrm{~m}$. In May, however, researchers from the University of Oxford found the kits to be insufficiently accurate. ${ }^{5}$ The tests were never used-half a million of them are sitting in storage-and the government is reportedly seeking a refund.

Self-testing kits display only a positive or negative result, with no further details. Finger-prick-style home tests are designed with a certain threshold of antigen reagent activity that will then show a positive or negative result. Depending on how the manufacturer set up the test, people could get a negative result even though they do have a small number of covid-19 antibodies in their blood-just not enough to get over the test kit's threshold and trigger the "positive" indicator. Furthermore, accurately placing a drop of blood into the test cartridge on some tests requires care, and it may not always be done correctly by the user.

Eleanor Riley, professor of immunology and infectious disease at the University of Edinburgh, says that it doesn't matter how many times you do one of these tests: very low levels of antibodies won't 
get picked up. Just as home pregnancy tests aren't infallible, self-test kits for covid-19 should never be used as definitive indicators of whether someone has had the virus, says Riley. A positive result should be seen as a prompt for further testing and confirmation, and a negative result doesn't mean that the person has never had the virus.

\section{What antibody tests are being used around the world?}

Crucially, no internationally accepted standard exists for covid-19 antibody tests, leaving governments to evaluate tests using their own criteria. This is a big problem, says Lawrence Young, professor of molecular oncology at the University of Warwick, as it means that no one can use a standard set of tests.

In the US, around a dozen antibody tests have been approved for use by the Food and Drug Administration, including those supplied by Roche and Abbott. ${ }^{6}$ Abbott has shipped more than 11 million antibody lab tests to healthcare organisations in the US so far. ${ }^{7}$

The Roche and Abbott tests are also being used in other countries including Germany, Italy, and, as mentioned, the UK, which has purchased 10 million lab antibody tests manufactured by these two companies. The UK is also developing its own finger-prick-style antibody tests through a consortium, with the aim of eventually distributing them to the public. ${ }^{8}$

Meanwhile, the UK's Medicines and Healthcare Products Regulatory Agency has taken action to prevent the sale of other commercial home testing kits that were previously available in the country. Such tests have not been validated, and any results from them should not be considered reliable, the UK agency has said. Australia recently found that one million finger prick antibody tests purchased by the government from two companies based in the US and China weren't accurate enough to be used.

Antibody tests continue to form part of several countries' strategies, particularly as governments look to ease lockdown measures and raise their test and trace capacity. Singapore has used antibody tests to aid contact tracing and surveillance efforts. Japan has said that it will complement PCR testing with antibody tests, citing their faster application and results and acknowledging the risk of false outcomes.

Furthermore, antibody tests can be useful for modelling how far covid-19 has spread in the community, particularly given the confusion over asymptomatic transmission. A study of antibody prevalence in 885 people in England recently suggested that about $7 \%$ of the population had been infected with SARS-CoV-2. ${ }^{9}$

Researchers in Germany found antibody evidence suggesting that $14 \%$ of its population had been infected with covid-19 so far. ${ }^{10}$ Japan has launched a pilot scheme to ascertain the extent of covid infections in three prefectures, including Tokyo, using antibody tests. And in Wuhan, China, only a few weeks out of lockdown, authorities have tested 9.9 million people using a mix of PCR and antibody tests to find out how widely the new coronavirus has spread in the place where covid-19 first emerged back in December.

\section{Does a positive antibody test result mean I'm immune?}

This is the question on most people's minds, but they shouldn't get their hopes up, says Simon Clarke, associate professor in cellular microbiology at the University of Reading. “There's been far too much said about immunity passports and [the suggestion that] 'If you've got antibodies, you're immune,"” he says.

Scientists still don't know what an ideal immune system response to covid-19 looks like. Antibodies may be very important, but so may the response of T cells, for example. It's possible that merely having antibodies isn't enough to prevent reinfection by the virus. And antibodies may also gradually disappear from someone's system over time-perhaps after a few months or years-potentially leaving that person vulnerable to SARS-CoV-2 again. Our immunity to the seasonal flu tends to last for about a year, but it's still unknown whether covid-19 will be the same, longer, or shorter.

And, as we've heard, the accuracy of antibody tests is still under review in many cases. People may get a false positive result showing that they have antibodies and may relax their attitude towards handwashing and social distancing.

"People are interested in these tests because they want certainty," says Riley. "The problem with the individual tests is they cannot give them that."

Competing interests: I have read and understood BMJ's policy on declaration of interests and have no relevant interests to declare.

Provenance and peer review: Commissioned, not peer reviewed.

Long QX, Liu BZ, Deng HJ, etal. Antibody responses to SARS-CoV-2 in patients with COVID-19. Nat Med 2020. doi: 10.1038/s41591-020-0897-1. pmid: 32350462

2 Center for Health Security. Global progress on covid-19 serology-based testing. 5 Jun 2020. https://www.centerforhealthsecurity.org/resources/COVID-19/serology/Serology-based-testsfor-COVID-19.html.

3 Public Health England. Evaluation of the Abbott SARS-CoV-2 IgG for the detection of anti-SARSCoV-2 antibodies. 8 Jun 2020. https://assets.publishing.service.gov.uk/government/uploads/system/uploads/attachment_data/file/890566/Evaluation_of_Abbott_SARS_COV_2_IgG_PHE.pdf.

4 Public Health England. Evaluation of Roche Elecsys AntiSARS-CoV-2 serology assay for the detection of anti-SARS-CoV-2 antibodies. 23 May 2020.

5 Kirkpatrick D, Bradley J. UK paid $\$ 20$ million for new coronavirus tests. They didn't work. New York Times 2020 Apr 16. https://www.nytimes.com/2020/04/16/world/europe/coronavirus-antibody-test-uk.html.

6 US Food and Drug Administration. EUA authorized serology test performance. Jun 2020. https://www.fda.gov/medical-devices/emergency-situations-medical-devices/eua-authorizedserology-test-performance.

7 Abbott. An update on Abbott's work on covid-19 testing. 28 May 2020. https://www.abbott.com/corpnewsroom/product-and-innovation/an-update-on-abbotts-work-on-COVID-19testing.html.

8 Association of British HealthTech Industries. Covid-19 testing update. 17 Apr 2020. https://www.abhi.org.uk/membership/members-area/updates/2020/april/covid-19-testing-update17042020/.

9 Roxby P. About 7\% have had coronavirus, says ONS survey. BBC News 2020 May 28. https://www.bbc.co.uk/news/health-52837593.

10 Germany ramps up antibody tests to determine coronavirus immunity Local (Germany) 2020 Apr 25. https://www.thelocal.de/20200425/germany-ramps-up-antibody-tests-to-determinecoronavirus-immunity.

This article is made freely available for use in accordance with BMJ's website terms and conditions for the duration of the covid-19 pandemic or until otherwise determined by BMJ. You may use, download and print the article for any lawful, non-commercial purpose (including text and data mining) provided that all copyright notices and trade marks are retained. 